\title{
STUDENTS' DEVELOPMENT IN THE LEARNING PROCESS
}

\author{
Vladimir D. Shadrikov \\ National Research University "Higher School \\ of Economics" (HSE) \\ Moscow, Russia
}

\begin{abstract}
A system genetics approach has been employed to study students' mental development. Ability development is considered in terms of mastering of intellectual operations. The study endeavors to identify the components of certain abilities consciously acquired by a student in the process of learning. The study was arranged in two directions: the teaching of students to master intellectual operations and use them in their work with training materials, and psychological testing of control and experimental student groups before and after training tests to diagnose the level of intellectual development. The study involved teachers and students of primary and secondary school.
\end{abstract}

Keywords: ability, intellectual operations, mental development, training activities, subject of activity, system genetics approach.

The system genetics approach to students' development allows shaping a harmonious personality by providing an intellectual (mental), moral and aesthetic development. Learning activity may encourage capacities for goal-setting and decision making, for drawing up the program, which provides goal achievement; it may help mould certain moral and emotional traits, as well as professionally important personal qualities, associated with goal achievement (volitional), or ability to express feeling and empathy; it may contribute to development of reflexivity. Learning activity forms a basis for the integrity of student's inner world. However, all this may be achieved only through appropriate educational content, and relevant methods of teaching and mentoring.

Among the above mentioned qualities we will dwell on the development of abilities. For this we have two reasons: firstly, the abilities are 
the key qualities that provide man's success in life, and secondly, we have theoretical explorations and practical experience of abilities' development.

\section{Development of abilities (theoretical backgrounds)}

A thesis formulated by L.S. Vygotsky in his theoretical study "The history of development of higher mental functions" suggests that development of higher mental functions is accomplished through mastering by the subject of one's own behavioral processes. In that respect, L.S. Vygotsky claimed, the history of mental functions had not yet been written. "The obscurity in genesis of higher mental functions inevitably leads to the essentially metaphysical conception: the higher and lower forms of memory, attention, and thinking exist in close quarters with each other and independently of one another, they are not genetically, functionally or structurally related, as if originally they were created in a double form" (Vigotsky, 1983). Along with the mechanical memory the logical memory, as its highest form, is distinguished, the voluntary attention is 'topped over' the involuntary attention, the creative imagination rises over the reproductive imagination, the imaginative thinking, as a second stage, uplifts the conceptual thinking and so on" (Ibid.). Unfortunately, the same apprehension is mostly maintained nowadays.

And now we may be at liberty to ask, what is actually meant by "mental functions acquisition"? It is the lack of theoretical explorations of the issue that inhibits its practical investigation. Anyway what does it really matter for the problem of human abilities?

The concepts of "ability" and "mental functions" have actually been studied separately, as two independent notions. However, these aspects of abilities development are too closely associated. Abilities development is based on functional systems, which implement specific mental functions, but at the same time, it is the process of development of culturally conditioned operating mechanism, mastering which an individual acquires his abilities. In this sense ability development appears as commingling of biological and cultural development.

Examination of studies concerning the psychology of abilities reveals that abilities are regarded in divorce with mental functions; that their determination by activity is brought into focus. An ambition to expose 
cultural determination of abilities, as opposed to their interpretation as internal latent properties, attributes, entities, leads to estrangement of natural and cultural ingredients of ability.

Psychological analysis reveals that any activity, practical or mental, might be decomposed into separate mental functions. Any activity brings forward something to be perceived, remembered, imagined, interpreted, decided upon, etc. Mental functions are the most common generic forms

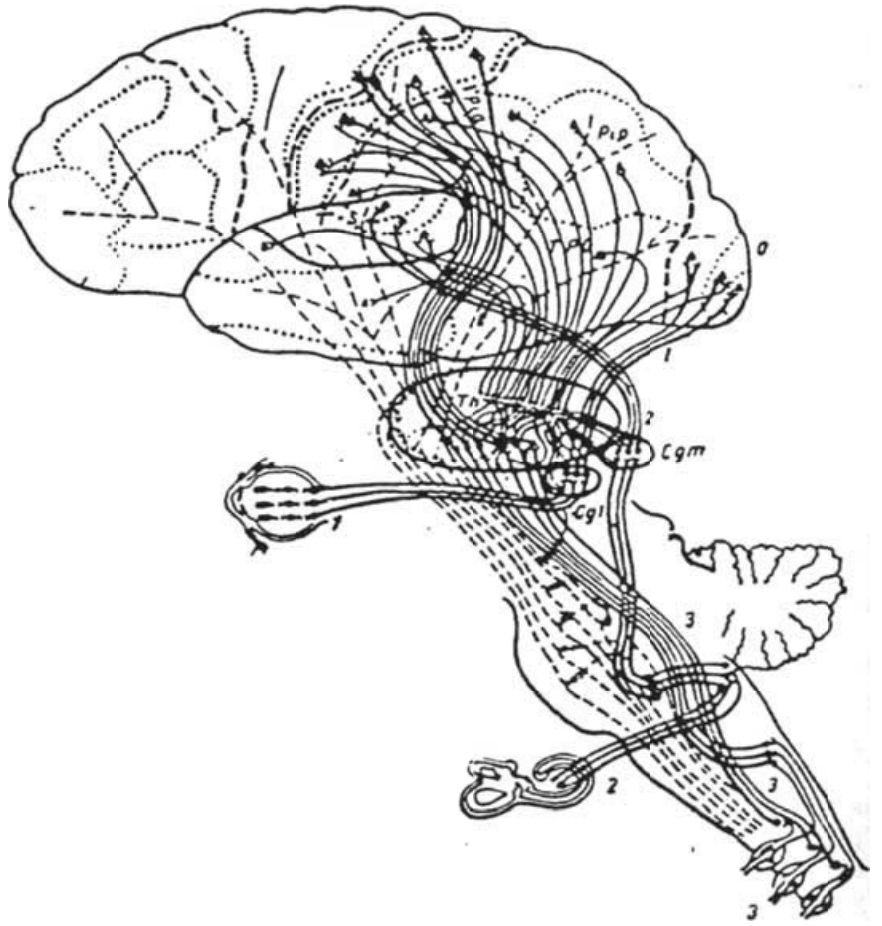

Figure 1. Afferent paths and sensory cortex zones

(G.I. Polyakov In. Luria, 1973).

Notes: In bold lines the system of analyzers with their switching in the subcortical regions is represented; 1 - visual analyzer; 2 - auditory analyzer; 3 - Skin-kinesthetic analyzer; $\mathrm{T}$ - temporal region; $\mathrm{O}$ - occipital region; Pip - box 39; Pia - field of 40; Pstc - postcentral area; SRW - frontal-parietal-occipital region; Th - thalamus; Cgm - internal geniculate body; $\mathrm{Cgl}$ - lateral geniculate body 
of activity. Psychophysiological studies have convincingly demonstrated that certain mental functions are implemented through complex neurophysiologic functional systems (Figure 1). In brain structure these functional systems are formed for realization of certain mental functions. It could be said that functional systems possess a quality, which allows carrying out certain mental functions. This quality of functional systems comes as a general natural ability in correlation with (relevant for) a specific mental function.

We have so far defined abilities in terms of the general, now we can examine them in terms of the singular and special. In this case abilities would be determined by how a certain general quality (an ability to perceive, memorize, etc.) is presented in a particular individual. The singularity will show itself in a measure to which a certain quality is represented in the individual. Quite naturally, the measure of a general quality may vary from individual to individual. At this stage there emerges an issue of individual differences in abilities as a variable measure of representation of a general capacity.

Thus, we can extend the definition of ability given above into the following: abilities are properties of functional systems, which realize specific mental functions, possess an individual measure of evidence and manifest themselves in efficiency and qualitative peculiarity of activity adoption and fulfillment.

The described approach reveals the nature of abilities and suggests a definition of individual abilities, which provided survival of an individual in natural conditions.

Having defined abilities in terms of properties of functional systems, we introduced the concept of 'ability' into the system of basic psychological categories.

As for the development of natural abilities (individual abilities) we should admit that we have but limited control over it. In this case ability development is directed at training of functional systems, which realize natural abilities. Obviously it is represented in the development of psychomotor skills (to take sport as an example).

To speak of actual control over mental abilities development we have to identify those components of abilities that are consciously acquired by a student.

This becomes possible when we turn from natural abilities to the abilities of subject activity. To leave details of the issue in question beyond the limits of the survey (Shadrikov, 2007), we should point out that natural abilities in their development might be completed by a system 
of intellectual operations. This process of abilities intellectualization comes down to integration of intelligence operations in realization of basic mental functions, such as perception, memory, imagination, representation and thinking. Table 1 contains a list of intellectual operations involved in the processes of perception, memory and thinking.

\section{Intellectual operations involved in the processes of perception, memory and thinking}

\begin{tabular}{|l|l|}
\hline Grouping & $\begin{array}{l}\text { material partition in accordance with certain criteria (meaning, } \\
\text { associations, gestalt rules, etc.) }\end{array}$ \\
\hline $\begin{array}{l}\text { Supporting } \\
\text { points }\end{array}$ & $\begin{array}{l}\text { selection of a divisible/multiple item which serves as a founda- } \\
\text { tion for a broader content (theses, titles, issues, images described } \\
\text { in the text, examples, digital data, comparisons, names, epithets, } \\
\text { unfamiliar or vaguely familiar words, sticking out expressions, } \\
\text { emotional reaction of the subject and etc.); }\end{array}$ \\
\hline Mnemonic plan & A set of supporting points \\
\hline Classification & $\begin{array}{l}\text { Assortment of objects, phenomena, or concepts into classes, } \\
\text { groups, and ranks on the bases of certain common characteristics }\end{array}$ \\
\hline Structuring & $\begin{array}{l}\text { establishment of mutual arrangement of parts that construct a } \\
\text { single whole, the internal structure of the memorized }\end{array}$ \\
\hline Systematization & $\begin{array}{l}\text { establishment of a certain order in arrangement of constituent } \\
\text { parts of the whole and interconnection between them }\end{array}$ \\
\hline Schematization & $\begin{array}{l}\text { representation or description of anything in the main or a simpli- } \\
\text { fied version of memorized information }\end{array}$ \\
\hline Analogy & $\begin{array}{l}\text { Recognizing similarity or correspondence between altogether dif- } \\
\text { ferent objects, phenomena, and concepts. }\end{array}$ \\
\hline $\begin{array}{l}\text { Mnemonic } \\
\text { techniques }\end{array}$ & A set of already existing, well-known means of memorizing \\
\hline Recoding & $\begin{array}{l}\text { verbalization or recitation, naming, shaping in an image-bearing } \\
\text { manner, refashioning an information on the basis of semantic, } \\
\text { phonemic markers, etc. }\end{array}$ \\
\hline $\begin{array}{l}\text { Completing } \\
\text { the memorized } \\
\text { material }\end{array}$ & $\begin{array}{l}\text { introduction suggested by the subject to memorized information: } \\
\text { the use of verbal mediators; incorporation and introduction of } \\
\text { something in accordance with a situation; distribution over the } \\
\text { places (the method of local binding or method of places) }\end{array}$ \\
\hline $\begin{array}{l}\text { Material arran- } \\
\text { gement in series }\end{array}$ & $\begin{array}{l}\text { establishment or setting of different sequences: ranging in vol- } \\
\text { ume, timing, ordering in space, etc. }\end{array}$ \\
\hline Association & $\begin{array}{l}\text { Establishment of relationships by similarity, contiguity or opposi- } \\
\text { tion, etc. }\end{array}$ \\
\hline Repetition & $\begin{array}{l}\text { The way of memorizing implying consciously controlled or un- } \\
\text { controlled processes of information circulation }\end{array}$ \\
\hline
\end{tabular}


Moreover, it should be noted that once intellectual activity is triggered, the processes of intellectualization emerge then and there. These are decision making processes, which consider what intellectual operations should be employed and in what way they might be used, the programming process which suggests how and in what succession selected operations are to be arranged, the process of criteria formation which indicates what operations should be preferred (criteria of preference), criteria of goal achievement, criteria of necessity and sufficiency of selected operations, criteria of efficacy of the results achieved.

The ability development in terms of mastering of intellectual operations, formation of intellectual skills including the operation of programming, decision making and use of different criteria, will characterize intellectualization of abilities. Table 2 presents a complete list of intellectual operations.

Table 2

\section{A complete list of intellectual operations}

\begin{tabular}{|c|c|c|c|}
\hline $\begin{array}{l}\text { Perception and } \\
\text { memory, thinking }\end{array}$ & Object-applied & $\begin{array}{l}\text { Conception } \\
\text { thinking }\end{array}$ & $\begin{array}{c}\text { Meta-intellectual } \\
\text { processes }\end{array}$ \\
\hline $\begin{array}{l}\text { Establishment of as- } \\
\text { sociations } \\
\text { Perceptual action } \\
\text { structuring } \\
\text { Regularized scanning } \\
\text { Mnemonic actions: } \\
\text { - grouping } \\
\text { - classification } \\
\text { - systematization } \\
\text { - analogies } \\
\text { - recoding } \\
\text { - mnemonic schemes } \\
\text { plotting (suppor- } \\
\text { ting items and con- } \\
\text { nections between } \\
\text { them, mnemonic } \\
\text { procedures, com- } \\
\text { pleting the memo- } \\
\text { rized material, } \\
\text { arrangement in } \\
\text { series) } \\
\text { - repetition }\end{array}$ & $\begin{array}{l}\text { Object manipu- } \\
\text { lation } \\
\text { Distinction } \\
\text { Comparison } \\
\text { Anchoring } \\
\text { Analysis } \\
\text { Synthesis } \\
\text { Generalization } \\
\text { Identification } \\
\text { of functional } \\
\text { meaning }\end{array}$ & $\begin{array}{l}\text { Analysis } \\
\text { Abstraction } \\
\text { Synthesis } \\
\text { Distinction } \\
\text { Intellectualization } \\
\text { of concepts } \\
\text { Comparison } \\
\text { Anchoring } \\
\text { Relationships } \\
\text { exposure } \\
\text { Generalization } \\
\text { Classification } \\
\text { Systematization } \\
\text { Definition } \\
\text { Reasoning } \\
\text { Judgments } \\
\text { Conclusion } \\
\text { Substantiation } \\
\text { Categorization } \\
\text { Coding } \\
\text { Identification }\end{array}$ & $\begin{array}{l}\text { Hypothesis genera- } \\
\text { tion } \\
\text { Goal-setting } \\
\text { Decision-making } \\
\text { Planning } \\
\text { Programming } \\
\text { Control } \\
\text { Self-reflection } \\
\text { Understanding } \\
\text { Values and meanings } \\
\text { clarification } \\
\text { Interpretation } \\
\text { Argumentation } \\
\text { Averment } \\
\text { Modeling } \\
\text { Mediation } \\
\text { Abilities }\end{array}$ \\
\hline
\end{tabular}



being.

Abilities of the subject of activity go far beyond those of a human

Skills development at the level of subject's activity can be represented as a process of mastering by the subject intelligence operations in their realization by specific mental functions. At this point we approach the issue that had been formulated by L.S. Vygotsky. That issue could not have been considered until we arrived at understanding of socialcultural nature of abilities. In this sense subject's abilities are considered as a unity of genetically and socially determined elements. Operation (acquisition) of one's abilities is possible only in the process of abilities' intellectualization.

The third line of abilities development is putting them under the control of moral qualities of the subject, under the control of conscience.

According to A. Bergson, intelligence and morality have always existed in a single entity during the whole history of mankind (Bergson, 1994). Mind and morality are mutually containing categories. And if we delve deeply into history, we will find that relations between mind and morality used to be far more intimate than they are represented in a contemporary man. Mind used to shape the moral commandment. Morality guided the community and individual's behavior within the community. This unity was gradually disrupted. They got separated in two lines of development: morality and intelligence. However, nowadays an action of the mind is still entangled with morality and controlled by it while morality betrays the presence of the mind.

Morality not only surfaces in specific decisions a mind should take, but more importantly, it defines the direction of search, embracing science and technology. Both mechanisms (morality and mind) initially traced in each other were to separate to develop independently. But even today each of them is reflected in the other, that is, there is an intimate connection between the two.

If we regard abilities at personality level yet another way of their acquisition is revealed. It is in putting one's abilities under subject's control, under the control of one's moral qualities and conscience.

The key point in abilities development is their determinacy by individual values. It is the individual values that determine qualitative specificity of abilities, they determine what individual will perceive and memorize, what ideas he will conceive, what character will form his personal consciousness. 
To sum up it could be asserted that conceptual definition of abilities is possible only if we consider them in three dimensions: individual, subject activity, and personality.

Human abilities in dimension of an individual are recognized in their natural (biological) essence. They have been shaped to provide human's surviving in the wild. Individual's abilities are the properties of functional systems, which implement specific mental and psychomotor functions, and have an individual measure of evidence and manifest themselves in efficiency and qualitative peculiarity of his cognition of objective world and organization of adaptive behavior (including vital activity).

Abilities of a human being in dimension of a subject of activity are developed on the basis of individual's natural abilities. The latter are encouraged by activity demands to acquire the features of operability, operational mechanisms develop; natural abilities are included in psychological functional systems that realize objective and mental activity. It can be asserted that human abilities in dimension of subject's activity are the properties of functional systems, in which structure individual's abilities (natural abilities) are functioning. Subject's activities like individual's abilities have an individual measure of evidence and manifest themselves in efficiency and qualitative peculiarity of adaptation and fulfillment of a certain activity.

Subject's abilities are manifestation of individual's abilities in a particular activity, which are completed by intellectual operations and realized in a developed form by a functional psychological system that is isomorphic to psychological activity system.

A key role in subject's abilities development belongs to the following processes:

- acquisition of abilities by the subject through mastering of intellectual operations;

- subtle adjustment of abilities to the activity conditions (to impart the features of operability to them (Oshanin, 1977).

Theoretical premises of mental abilities development enable us to proceed to some practical issues of abilities development. 


\section{Developing the abilities of the subject of learning activity (student)}

The study was conducted during 2007-2008 and 2008-2009 school years in the secondary school № 507 in Moscow with the pupils of primary and secondary school. The study was conducted with participation of the researchers of The Institute of Educational Content of The National Research University «Higher School of Economics» (N.A. Zinovieva, M.D. Kuznetsova, N.V. Schreider) and school teachers (V.D. Boikova, O.E. Korobkova, E.V. Stepanova).

The study design included:

- the teaching of pupils to master intellectual operations and use them in work with training materials;

- psychological testing of control and experimental pupil groups before and after training tests that diagnose the level of intellectual development.

Pupils in six classes (three experimental and three control classes) have taken part in the study.

At the preliminary stage the teachers participating the experiment were introduced to the basic theoretical propositions of abilities theory (Shadrikov, 2007). The postulate that development of abilities is achieved through mastering of intellectual operations was particularly thrashed out.

On the research stage - during the initial phase - the teachers were teaching the pupils the content and composition of basic intellectual operations. Infallible identification of each intellectual operation by a pupil was a criterion of its mastering.

The next phase introduced intellectual operations into the process of content studying of a particular discipline. The teacher would demonstrate what intellectual operations were actually represented during the learning of educational material; he would focus the pupils' attention on the employed intellectual operations (development of reflection in relation to the operations in use).

At the third stage of the study teachers would proceed to its main objective - the use of intellectual operations in learning activity as a method of development of cognitive capacities and the improvement of quality in discipline teaching. 
This might be illustrated with lessons layout of a teacher O.E. Korobkova which taught history in the fifth form: an experimental group - "B" (21 pupils), the controlling group - "A" (22 pupils). The experiment was conducted from December, 2008 till May, 2009.

A topic-calendar planning for a fragment of history course "The history of Ancient World" (for the fifth form) with indication of lessons included at the third experiment stage is represented in Table 3.

Table 3

\section{Topic-calendar planning for the course "The history of the Ancient World"}

\begin{tabular}{|c|c|c|}
\hline Topic & Experiment & Materials \\
\hline \multicolumn{3}{|c|}{ Section III. Ancient Greece civilization } \\
\hline $\begin{array}{l}\text { Topic 6. The origin of ancient Greek } \\
\text { civilization. Archaic period. } \\
\text { Nature and population of the ancient } \\
\text { Greece. Cretan kingdom. Mycenaean } \\
\text { kingdom. Homer's poem "Iliad" as } \\
\text { a cultural property and a historical } \\
\text { source. Homer's poem "The Odyssey" }\end{array}$ & \begin{tabular}{|c|} 
Lesson 15. \\
Discernment, \\
analysis, compari- \\
son, connections \\
establishment
\end{tabular} & $\begin{array}{l}\text { Illustrations for } \\
\text { presentation, working } \\
\text { with a textbook, the } \\
\text { Atlas, and a note- } \\
\text { book. }\end{array}$ \\
\hline The ancient Greek city-states. & $\begin{array}{l}\text { Lesson } 16 . \\
\text { Discernment, } \\
\text { analysis, synthesis, } \\
\text { reasoning, identifica- } \\
\text { tion of meanings }\end{array}$ & $\begin{array}{l}\text { Working with a note- } \\
\text { book, a textbook, and } \\
\text { charts. }\end{array}$ \\
\hline $\begin{array}{l}\text { Ancient Sparta. Ancient Athens. } \\
\text { The Origin of Athens Democracy. } \\
\text { Greek colonization. }\end{array}$ & $\begin{array}{l}\text { Lesson } 17-19 . \\
\text { Analysis, compari- } \\
\text { son, analogy }\end{array}$ & \\
\hline $\begin{array}{l}\text { Self-guided work. The lesson in } \\
\text { recapitulation and generalization on } \\
\text { "Ancient Greece Policies" }\end{array}$ & Test № 4. & \\
\hline $\begin{array}{l}\text { Topic 7. The Classical period in the } \\
\text { history of ancient Greece. Ancient } \\
\text { Greek culture. Greece-Persian Wars. } \\
\text { The Persian Invasion led by King } \\
\text { Xerxes. The Rise of Athens and the } \\
\text { flowering of democracy. Athenian } \\
\text { philosophy schools. Scientific knowl- } \\
\text { edge shared by ancient Greeks. }\end{array}$ & $\begin{array}{c}\text { Lesson } 20 . \\
\text { Comparison, } \\
\text { analysis, synthesis, } \\
\text { interpretation }\end{array}$ & $\begin{array}{l}\text { Working with the } \\
\text { contoured map, a } \\
\text { questionnaire. }\end{array}$ \\
\hline $\begin{array}{l}\text { All-Greek celebrations. Olympic } \\
\text { games. }\end{array}$ & \multirow{2}{*}{$\begin{array}{l}\text { Lesson } 21-23 . \\
\text { Discernment, } \\
\text { analysis, compari- } \\
\text { son, links establish- } \\
\text { ment and analogical } \\
\text { thinking } \\
\text { Test № } 5 . \\
\end{array}$} & $\begin{array}{l}\text { Textbook, notebook, } \\
\text { table }\end{array}$ \\
\hline $\begin{array}{l}\text { Religion in Ancient Greece. The Art } \\
\text { of Ancient Greece. The origin of an } \\
\text { ancient theater. }\end{array}$ & & $\begin{array}{l}\text { Illustrations for pres- } \\
\text { entation; } \\
\text { A textbook, a note- } \\
\text { book, table. Test. }\end{array}$ \\
\hline
\end{tabular}




\begin{tabular}{|c|c|c|}
\hline $\begin{array}{l}\text { Topic 8. The Hellenistic period of } \\
\text { ancient Greek civilization. The rise } \\
\text { of Macedonia. Subdual of Hellas. } \\
\text { Creation and disintegration of Alex- } \\
\text { ander's empire. Hellenistic culture. }\end{array}$ & $\begin{array}{l}\text { Lesson } 24 . \\
\text { Comparison, } \\
\text { analysis, synthesis, } \\
\text { interpretation }\end{array}$ & $\begin{array}{l}\text { Working with con- } \\
\text { tour maps, Atlases, } \\
\text { textbooks. }\end{array}$ \\
\hline $\begin{array}{l}\text { The lesson of recapitulation and gen- } \\
\text { eralization on "Ancient Greece" }\end{array}$ & $\begin{array}{c}\text { Lesson } 25 . \\
\text { Reasoning, gener- } \\
\text { alization, links estab- } \\
\text { lishment, analogy } \\
\text { Test № } 6 .\end{array}$ & Presentation \\
\hline \multicolumn{3}{|c|}{ Section IV. Civilization of Ancient Rome } \\
\hline $\begin{array}{l}\text { Topic } 9 . \text { The Infancy of Roman } \\
\text { civilization.-Nature and population } \\
\text { of Ancient Italy. }\end{array}$ & $\begin{array}{l}\text { Lesson } 26 . \\
\text { Discernment, analy- } \\
\text { sis, comparison, } \\
\text { links establishment }\end{array}$ & $\begin{array}{l}\text { Working with a text- } \\
\text { book, the Atlas and a } \\
\text { notebook }\end{array}$ \\
\hline $\begin{array}{l}\text { The overthrow of monarchy and the } \\
\text { establishment of Republic in Rome. } \\
\text { The conquest of Italy by Rome. }\end{array}$ & $\begin{array}{c}\text { Lesson } 27 . \\
\text { Analysis, synthesis, } \\
\text { interpretation }\end{array}$ & $\begin{array}{l}\text { Notebook, chart, a } \\
\text { textbook }\end{array}$ \\
\hline $\begin{array}{l}\text { Topic } 10 \text {. The Power and fall of } \\
\text { Roman Republic. Punic Wars. The } \\
\text { Roman conquest of Eastern Mediter- } \\
\text { ranean. }\end{array}$ & $\begin{array}{l}\text { Lesson } 28 . \\
\text { Comparison, } \\
\text { analysis, synthesis, } \\
\text { interpretation }\end{array}$ & $\begin{array}{l}\text { Working with con- } \\
\text { toured maps, Atlases, } \\
\text { and a textbook }\end{array}$ \\
\hline $\begin{array}{l}\text { Everyday life of a Roman in Golden } \\
\text { Age of the Republic. Civil wars } \\
\text { and slave rebellions in the Roman } \\
\text { Republic. }\end{array}$ & $\begin{array}{l}\text { Lesson } 29 . \\
\text { Comparison, ana- } \\
\text { logical thinking, the } \\
\text { argument }\end{array}$ & $\begin{array}{l}\text { Notebook, textbook, } \\
\text { table }\end{array}$ \\
\hline $\begin{array}{l}\text { The fall of the Roman Republic. } S / R \text {, } \\
\text { "Republican Rome". }\end{array}$ & $\begin{array}{c}\text { Lesson } 30 . \\
\text { Interpretation }\end{array}$ & $\begin{array}{c}\text { Further readings, a } \\
\text { notebook }\end{array}$ \\
\hline $\begin{array}{l}\text { Topic 11. Roman Empire as a } \\
\text { world power. The power of Roman } \\
\text { emperors. Architecture and building } \\
\text { in Roman Empire. The outburst and } \\
\text { spreading of Christianity within the } \\
\text { Roman Empire. }\end{array}$ & $\begin{array}{l}\text { Lesson } 31 . \\
\text { Discernment, analy- } \\
\text { sis, comparison }\end{array}$ & $\begin{array}{l}\text { Presentation, work- } \\
\text { ing with the scheme }\end{array}$ \\
\hline $\begin{array}{l}\text { The Empire and Barbarians. The Fall } \\
\text { of Western Roman Empire. }\end{array}$ & $\begin{array}{l}\text { Lesson } 32 . \\
\text { Comparison, } \\
\text { analysis, synthesis, } \\
\text { interpretation }\end{array}$ & $\begin{array}{l}\text { Working with con- } \\
\text { toured maps, Atlases, } \\
\text { textbooks }\end{array}$ \\
\hline $\begin{array}{l}\text { The lesson of recapitulation and } \\
\text { generalization }\end{array}$ & $\begin{array}{l}\text { Lesson } 33 . \\
\text { Learned intellectual } \\
\text { operations } \\
\text { Testing course work } \\
\text { "History of the An- } \\
\text { cient World" }\end{array}$ & $\begin{array}{l}\text { Working with hand- } \\
\text { out material }\end{array}$ \\
\hline Conclusive repetition & & \\
\hline
\end{tabular}


The final work results of verification of intellectual operations mastering are represented in Table 4.

Table 4

Conclusive results of the fifth " $A$ " and " $B$ " classes marked in a percentage

\begin{tabular}{|c|l|c|c|c|c|c|c|}
\hline$№$ & $\begin{array}{l}\text { Checked intellectual } \\
\text { operation (IE) }\end{array}$ & \multicolumn{2}{|c|}{ Correct answers } & \multicolumn{2}{c|}{$\begin{array}{c}\text { Partially correct } \\
\text { answers }\end{array}$} & \multicolumn{2}{|c|}{$\begin{array}{c}\text { Incorrect, miss- } \\
\text { ing answers }\end{array}$} \\
\hline & & “A" & "B" & “A" & “B” & “A" & "B" \\
\hline $\mathbf{1}$ & Distinction & 81 & 94 & 19 & 6 & 0 & 0 \\
\hline $\mathbf{2}$ & Comparison & 10 & 50 & 33 & 33 & 57 & 17 \\
\hline $\mathbf{3}$ & Distinction, anchoring & 57 & 83 & 28 & 17 & 15 & 0 \\
\hline $\mathbf{4}$ & Analysis & 33 & 66 & 52 & 23 & 15 & 11 \\
\hline $\mathbf{5}$ & Argumentation & 19 & 83 & 38 & 6 & 43 & 11 \\
\hline $\mathbf{6}$ & $\begin{array}{l}\text { Correspondence, } \\
\text { distinction }\end{array}$ & 76 & 78 & 0 & 0 & 24 & 22 \\
\hline $\mathbf{7}$ & Interpretation & 38 & 66 & 43 & 28 & 19 & 6 \\
\hline $\mathbf{8}$ & Generalization & 19 & 39 & 33 & 23 & 48 & 38 \\
\hline
\end{tabular}

The given data have indicated that the experimental group basically performed a better accomplishment of the task in comparison, analysis, reasoning, visual anchoring, and interpretation. Hence, these intellectual operations are efficiently shaped only with teacher's deliberate encouragement. The IO of generalization is equally difficult for pupils of both classes. It requires a more complex intellectual activity: to select the objects (to distinguish them), to discover their essential features (analysis), to identify their common features, to join them into a group and name it. Therefore, it is the most complicated intellectual operation.

The results of this work are presented in Table 5.

Table 5

Comparison of marks for final test working

\begin{tabular}{|c|c|c|}
\hline Mark & Experimental group (5 “B”) & Control group (5 “A”) \\
\hline$« \mathbf{5} »$ & $27 \%$ & $0 \%$ \\
\hline$« 4 »$ & $55 \%$ & $39 \%$ \\
\hline$« \mathbf{3} »$ & $18 \%$ & $47 \%$ \\
\hline$« \mathbf{2} »$ & $0 \%$ & $14 \%$ \\
\hline Quality percentage & $82 \%$ & $39 \%$ \\
\hline $\begin{array}{c}\text { Educational success } \\
\text { percentage }\end{array}$ & $100 \%$ & $86 \%$ \\
\hline
\end{tabular}




\section{Psychological Testing}

The experimental teaching data were compared with testing results in the experimental and control groups according to Wechsler IQ test (5 subtests) and the Cultural-independent Cettell's test.

In accordance with the assessment technique of D. Wechsler "Vocabulary" IQ subtest, the analysis has been made with average scores that reflect the quality of interpretation, the level of analysis and synthesis, an adequate understanding and description of values and meanings presented in the subtest's words.

The test accomplishment indicates that pupils of the experimental group have reliably better coped with suggested tasks and have given more detailed, precise, and generalized answers based on key criteria for the definition (Table 6, Figure 2).

Table 6

Quality interpretation of basic intellectual operations (thinking) revealed in the experimental and control groups (5th form pupils)

\begin{tabular}{|c|c|c|}
\hline Major IE (thinking) & Experimental group & Control group \\
\hline Analysis & 1,88 & 1,10 \\
\hline Synthesis & 1,63 & 0,30 \\
\hline Comparison & 0,81 & 1,05 \\
\hline Distinction & 1,81 & 1,05 \\
\hline Analogical thinking & 0,63 & 0,55 \\
\hline Links establishment & 0,69 & 1,20 \\
\hline Abstracting & 0,19 & 0,20 \\
\hline Generalization & 1,69 & 1,10 \\
\hline Comparison & 2,31 & 1,40 \\
\hline Interpretation & 0,25 & 0,00 \\
\hline $\begin{array}{c}\text { Identification of values and } \\
\text { meanings }\end{array}$ & 0,81 & 0,25 \\
\hline Argumentation & 1,19 & 0,30 \\
\hline Averment & 1,63 & 1,45 \\
\hline
\end{tabular}




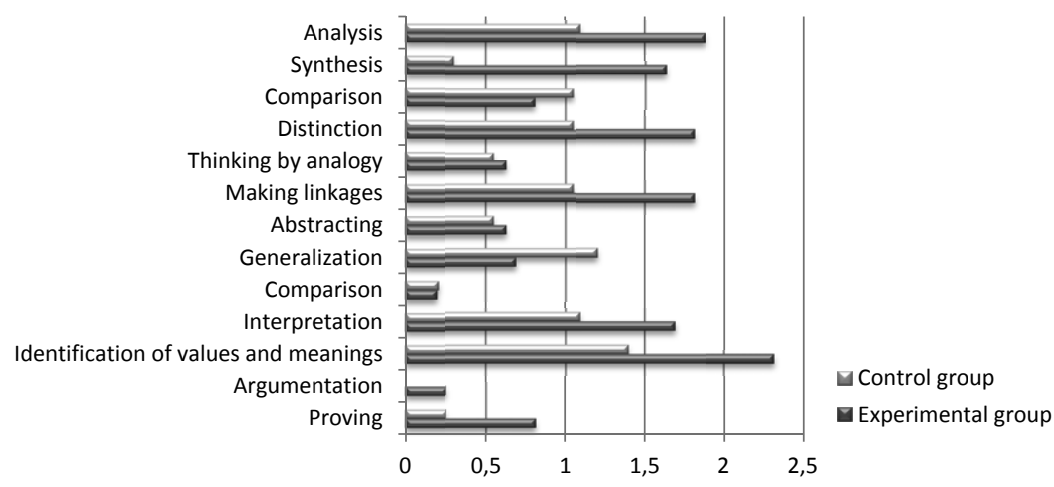

Figure 2. Experimental and control groups (5th form) pupils' quality interpretation of basic intellectual operations

Notes: 0 - students do not know the meaning of the term; 3 - students give an accurate, comprehensive definition.

These data are graphically illustrated in Figure 2.

Differences between the experimental and control groups in terms of the efficiency in accomplishment of a testing task turn out to be statistically significant with a probability of $0.95(\mathrm{p}<0,05)$. Thus, the data received indicate that students taught in accordance with a special development program are more apt to use such operations as analysis, synthesis, abstraction, generalization, interpretation and identification of the values and meanings, reasoning and averment. They also demonstrate the higher results on the level of verbal intelligence.

The comparison of Cettell's test results for experimental and control groups are represented in Table 7 and Figure 3.

Table 7

Mean scores derived from Cettell's IQ culturally independent test for pupils of experimental and control groups (5th form)

\begin{tabular}{|c|c|c|}
\hline & Experimental group & Control group \\
\hline Task 1 & 10,11 & 8,38 \\
\hline Task 2 & 9,67 & 9,56 \\
\hline Task 3 & 9,17 & 8,69 \\
\hline Task 4 & 5,56 & 4,50 \\
\hline Total score & 34,50 & 31,06 \\
\hline
\end{tabular}




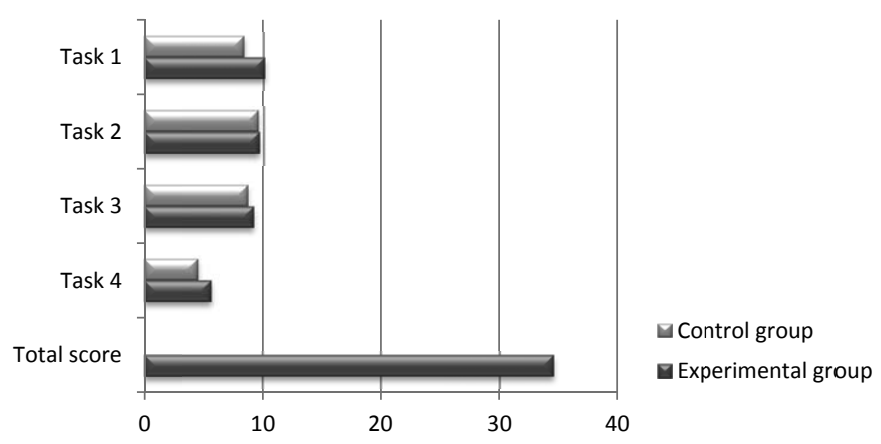

Figure 3. Experimental and control group (5th form) pupils' mean scores derived from Cettell's IQ culturally independent test.

The analysis of obtained results testifies to the fact that the experimental group participants definitely better accomplished suggested tasks than participants of the control group. The $U$ criterion of MannWhitney employed in reckoning has indicated the significance of differences with a probability of $0.99(\mathrm{p}<0,01)$.

Table 8 and Figure 4 display dynamics of the power in accomplishment of Cettell's test in three cross-sections.

Table 8

Dynamics in accomplishment of Cettell's IQ culturally independent test among pupils of experimental and control group (5th form)

\begin{tabular}{|c|c|c|}
\hline Data & Experimental group & Control group \\
\hline Primary & 29,32 & 29,62 \\
\hline Intermediary & 32,89 & 29,71 \\
\hline Totals & 34,50 & 31,06 \\
\hline
\end{tabular}

Intermediary and conclusive results in the experimental group differ within a probability of $0.99(\mathrm{p}<0,01)$.

Hence, it could be stated that purposive development of cognitive abilities with pupils brings a considerable advancement of their intellectual powers, which improves the quality of teaching.

In the experimental group results of the test accomplishment increased by 5.18 points, in the control group - only by 1.44 points. The 


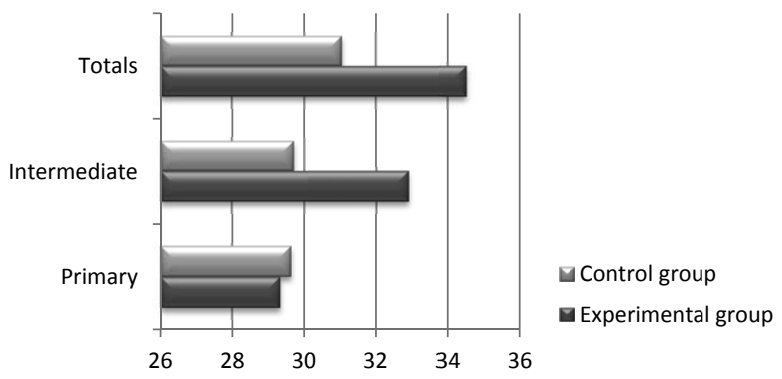

Figure 4. Dynamics in accomplishment of Cettell's IQ culturally independent test in experimental and control groups of pupils (5th form).

intelligence level in the experimental group increased by $17.7 \%$ while in the control group - only by 4.9\%. The difference is about 12,8\%.

To our opinion, this is a remarkably high index, which indicates that intellectual operations and the mastering of these operations have a considerable impact on psychogeny. The increase in the power of test accomplishment observed in the control group may be fairly explained by the fact that students' intelligence is developed through the process of traditional learning, however, this figure is considerably lower than that of the experimental group (4,9\% $17,7 \%)$.

Individual observations indicate that there is transfer of intellectual skills from one object to another. Nevertheless, this aspect requires further investigation.

It was essential for the analysis of the study that the teacher participating in the experimenter was to work in both, the control and experimental classes. We would deliberately specify it in question whether one's teaching activity was automatically transferred from the experimental to the control group. We would receive the following reply: "I have tried to avoid it. It's hard to say, though, how much I have succeeded in it". However, in conducting such experiments it is difficult to choose another scheme because we cannot foresee, in what way and to which extent an individual style of another teacher's as well as the level of his or her qualification might interfere with the results. The given artifact should much emphasize the differences in the experimental and control groups. 


\section{Acknowledgments}

The study was accomplished in 2011 in the framework of the Basic Research Program “Teachers' training to develop students' abilities" supported by National Research University of Higher School of Economics.

\section{References}

Bergson, A. (1994). Dva istochnika morali i religii [The two sources of morality and religion]. Moscow: Kanon.

Oshanin, D.A. (1977). Kontseptsiya operativnogo otrazheniya v inzhenernoy i obshchey psyhologii [The concept of operational reflection in engineering and general psychology]. In: Inzhenernaya psihologiya [Engineering psychology] (pp. 134-149). Moscow: Nauka.

Shadrikov, V.D. (2007). Mental'noe razvitie cheloveka [Mental development of a human]. Moscow: Aspekt Press.

Vygotsky, L.S. (1983). Sobranie sochineniy [Collected works], in 6 volumes. Vol. 3. Moscow: Pedagogika. 